\title{
Positive Autism: Investigation of Workplace Characteristics Leading to a Strengths-Based Approach to Employment of People with Autism
}

\author{
Peter S. WONG \\ Michelle DONELLY' \\ Philip A. NECK ${ }^{3}$ \\ Bill BOYD
}

\begin{abstract}
United Nations declares that employment is a basic human right. Numerous public policies reference the devastating impact of unemployment on health and social inclusion and seek to promote the economic participation of people with disabilities. Some researchers reckon high levels of economic marginalisation are experienced by people with a disability in Australia, in comparison with other OECD countries.

In the literature, $80 \%$ unemployment rates are reported among working-age people with autism spectrum disorder (ASD). This is a critical area of concern that is currently underresearched and poorly addressed.

"ASD-ness" (ASD behavioural characteristics) can be regarded as personal differences rather than disorders. Acknowledged experts such as Drucker and Cliffton \& Harter argue that individuals gain more when they build on their talents rather than focusing on improving weaknesses. The authors, therefore, take an ASD-ness-strengths-based approach philosophy which, in a nutshell, regards ASD-ness as a source of employment strengths and autistic behavioural challenges as personal differences not deficits.
\end{abstract}

Keywords: positive autism, strengths-based, employment, Drucker, knowledgeworker productivity, entrepreneurship, human rights, social well-being

JEL classification: E24, J24, 015

DOI: $10.24818 / \mathrm{RMCl} .2018 .1 .15$

\footnotetext{
${ }^{1}$ Peter S. Wong, School of Health and Human Sciences, Southern Cross University, QLD 4225, Australia, E-mail: petersunsanwong@gmail.com, Tel: +61 266795566

${ }^{2}$ Michelle Donelly, School of Health and Human Sciences, Southern Cross University, QLD 4225, Australia, E-mail: michelle.donelly@scu.edu.au, Tel: +61 755893241

${ }^{3}$ Philip A. Neck, School of Health and Human Sciences, Southern Cross University, QLD 4225, Australia, E-mail: philip.neck@scu.edu.au, Tel: +61 755069365

${ }^{4}$ Bill Boyd, School of Environment, Science and Engineering, Lismore, Australia, E-mail: william.boyd@scu.edu.au, Tel: +61 0266203569
} 


\section{Introduction}

"Autism is a condition that defies simple generalisations. Except one: the potential of far too many autistic people is being squandered. Although around half of those with autism are of average intelligence or above, they do far worse than they should at school and at work... Globally, the United Nations reckons that $80 \%$ of those with autism are not in the workforce... These numbers represent a tragic toll, as millions of people live idle and isolated outside the world of work" (The Economist, April 16, 2016, p 9).

The term autism can be described as a distinct category of developmental disabilities that share many of the same characteristics.

The behavioural characteristics of Autism Spectrum Disorder (ASD) are described in the Diagnostic and Statistical Manual of Mental Disorders (2013). Although people with ASD are all different, they all display "persistent deficits in social communication and social interaction across multiple contexts, as manifested by the following, currently or by history" (DSM-5, 2013, p. 50) in -

- Social-emotional reciprocity; and

- Nonverbal communication used in social interaction; and

- Developing, maintaining and understanding relationships.

Additionally, they may display "restricted, repetitive patterns of behaviour, interests, or activities, as manifested by at least two of the following, currently or by history" (DSM-5, 2013, p. 50) in

- Stereotyped or repetitive motor movements, use of objects, or speech; or

- Insistence on sameness, inflexible adherence to routines, or ritualized patterns or verbal nonverbal behaviour; or

- Highly restricted, fixated interests that are abnormal in intensity or focus; or

- Hyper- or hypo- reactivity to sensory input or unusual interests in sensory aspects of the environment.

In DSM-5, autism is defined as a spectrum of disorders, which include Kanner's autism (Kanner, 1943); Asperger Syndrome (Asperger, 1944) and pervasive developmental disorder-not otherwise specified (PDD-NOS). Kanner's autism is often regarded as the most severe form of ASD. ASDs are believed to be "permanent developmental disorders that will continue into adulthood, creating lifelong challenges for the individual" (Hendricks, 2009 p. 125).

Hence,

"The vast majority of autistic people cannot get a job - and when they do, bullying in the workplace seems to be on the rise. These are just two of the shocking findings in a new survey released today by the National Autistic Society, which is launching a petition for change" (The Guardian, Oct 27th 2016).

"Just $16 \%$ of autistic adults are in full-time paid employment. And, in almost a decade, this appalling situation hasn't improved. We are determined to change this ... Once autistic people are work ready, many still face unnecessary difficulties when applying for a job and, 
if they get one, [they face] further barriers in the workplace." (The National Autism Society, 2016).

Autistic behavioural "disorders" often continue throughout adulthood (Matson \& Rivet 2008) and contribute to challenges in employment for people with autism. The unemployment rates among people with autism are alarmingly high at 80\% (Ban, 2015; Dudley, Nicholas \& Zwicker, 2015). A growing population of adolescents diagnosed with autism are graduating from high school with limited employment opportunities (Roux et al, 2013). Promoting employment participation for people with autism is an important research issue that is currently not being adequately addressed (Ratto \& Mesibov 2015, Billstedt et al. 2007; Seltzer et al. 2011; Shattuck et al. 2007). Despite the importance of research into adulthood in autism being a means of "improving the quality of life and functioning of adults with autism, with the overall goal of enabling adults to lead fulfilling and productive lives in the community" (Orsmon et al, 2013 p. 271), in Australia, 99\% of all current autism research focuses on the early years and school years (Autism CRC, 2015). In the United Kingdom, some researchers have called for autism research to focus "in those areas that make a difference to people's day-to-day lives" (Pellicano, Dinsmore \& Charman, 2014, p. 756).

In the United States, the Interagency Autism Coordinating Committee (IACC) indicated in its 2017 strategic plan that -

"Research focused on adult issues has lagged far behind other types of ASDrelated research, comprising only $2 \%$ of all autism research spending in 2015." (IACC 2017 p. 83)

Roux et al. (2013) stated that young adults with ASD have lower employment rates than other disability groups. In a study by Shattuck et al. (2012), 55\% of young adults with ASD, in the first six years after high school, were found to have never worked, not even one paid job, other than home-based work. For those who are in employment, most work in sheltered workshop environments (Taylor, et al., 2012). People with ASD of average to above average intellectual ability experiences similar challenges in establishing and retaining employment (Howlin, Alcock \& Burkin, 2005; Barnhill, 2007).

In the United States, the "10 Years of Progress Report: What We've Learned about Autism" (2016) indicates (Autism speaks, 2016):

- Autism's prevalence has skyrocketed from 1 in 166 ten years ago to 1 in 68 today.

- Direct screening suggests that autism's prevalence may be even higher.

- Nearly half of 25-year-olds with autism have never held a paying job.

- Most adults with autism (84\%) remain living with their parents.

- Each year, an estimated 50,000 teens with autism leave school-based autism services as they reach graduation age.

- The cost of autism to families and society across a lifetime averages $\$ 1.4$ million to $\$ 2.4$ million.

UN Secretary-General António Guterres' message (United Nations, 2017) on World Autism Awareness Day indicated that. 
"As the United Nations Convention on the Rights of Persons with Disabilities points out, legal capacity and equal recognition before the law are inherent rights that persons with autism enjoy on an equal basis with other members of our societies ...

When they enjoy equal opportunity for self-determination and autonomy, persons with autism will be empowered to make an even stronger positive impact on our shared future."

The importance of workforce participation for social inclusion, health and well-being (Kivimäki et al., 2001; Artazcoz et al., 2004; Kim et al., 2015) and the low work participation rates of people with autism, combined with the estimated limited [1\%] autism research in Australia, currently focused on post-school participation (Autism CRC, 2015) led to the identification of the following research problems -

Research problem one: Employment participation of people with ASD appears to be a critical area that is currently under-researched and poorly addressed.

In the literature, from a sociological perspective, historically, the social and the medical models of disability have been used to identify and address barriers to employment participation for people with disabilities. However, both the social and medical models of disability appear to strategize policies focusing on the person with a disability and their lack of skills and abilities (medical model) or the barriers to participation including physical, sensory, organisational, legislative and attitudinal barriers (United Nations, 2014). Less emphasis is placed on the workplace leadership/and or management models as the key to resolving the issue of employment participation for people with disabilities and the complex interactions between the embodied experience of impairment and organisational practices (Falkmer, 2018). This has led to the identification of:

Research problem two: There appears to be a lack of strategies and management models addressing issues of employment for people with ASD.

To address the two research problems relating to employment participation for people with ASD, two research questions were developed -

Research question one: What are the workplace factors critical for improving employment for people with ASD? be improved?

Research question two: How can employment participation for people with ASD

From the research questions, two research objectives were developed to specifically address workforce and employment management (as opposed to medical or social) needs.

Research objective one: To identify and examine the factors influencing the employment participation of people with ASD in competitive employment."

Research objective two: "To build an employment model that addresses factors critical for the employment participation of people with ASD in competitive employment." 


\section{Positive Autism}

To address these critical research objectives, the authors take the view that "Individuals gain more when they build on their talents, than when they make comparable efforts to improve their areas of weakness" (Clifton \& Harter, 2003, p. 111).

Many psychotherapists find that

"Concentrating on failures and inadequacies ... can make patients feel worse rather than better, at least in the short run. If the focus on shortcomings and mistakes continues, the patient's self-esteem may decline and the situation may deteriorate." (Harvard Mental Health Letter, 1999).

Instead of identifying the two broad characteristics of people with ASD (DSM-5, 2013): as deficits in social communication/interaction (SC/I), and restricted/repetitive behaviours, interests and activities, some researchers (Pickavance, 2014; Lorenz \& Heinitz, 2014; Harrop \& Kasari, 2015) believe autistic restrictive, repetitive patterns of behaviour, interests, or activities (R/RBIA) can be seen as strengths because they think and focus differently:

"SAP [SystemAnalyse und Programmentwicklung] said that by 2020, 1 per cent of its global workforce of 65,000 employees would be people with autism. The company said it believes that 'innovation comes from the edges', and only by employing people who think differently and spark innovation will SAP be prepared to handle the challenges of the 21 st century" (Pickavance, 2014 p. 139).

Whether it is SAP campaigning for workplace neurodiversity, or big businesses in science, technology, engineering and mathematics (STEM) seeking to harness the unique talents of people with ASD, they are suddenly in demand for their obsessive "concentration during long-lasting routine work, identification of logical rules and patterns, processing visual information, and the ability to remember facts, surpass neural-typical individuals" (Lorenz \& Heinitz, 2014 p. 1).

Difficulties in social communication/interaction (SC/I) skills in areas such as empathy, social skills, emotional control or flexibility (Kapp et al., 2012) may need to be accommodated to harness the identified employment strengths. While therapies to improve $\mathrm{SC} / \mathrm{I}$ have rapidly advanced, the reasons, the mechanism, and the management of R/RBIA are still unclear (Harrop \& Kasari, 2015). Making uninformed attempts to intervene may not be beneficial or welcomed by the autistic community particularly as the same characteristics can turn out to be valued strengths not deficits.

$\operatorname{Kral}(1989$, p. 32) believes that

"If we ask people to look for deficits, they will usually find them, and their view of the situation will be colored by this. If we ask people to look for successes, they will usually find them, and their view of the situation will be colored by this."

Arguably, when deficits are viewed as individual differences, focusing on the ASD-ness (ASD behavioural characteristics) that could be employment strengths for people with ASD rather than balancing their strengths and deficits, opens doors to establishing and retaining competitive employment for people with ASD. As such, 
the focus of this research is a strengths-based approach to employment success addressing the factors affecting the "employee-retention of people with ASD in competitive employment" and autistic behavioural challenges as personal differences not deficits.

\section{Auto-Ethnography}

Given the reality of the lived experience of people with autism in the workforce, a very good place to examine that experience is from the personal perspective of someone who has lived with autism and experienced the effects this has had upon employment. This paper, therefore, commences from an auto-ethnographic perspective, working towards a broader model of workplace acceptance of autism.

Auto-ethnography, largely based on autobiographic vignettes (anecdotes) and ethnographic accounts. This method is "a form of research that involves selfobservation and reflexive investigation in the context of ethnographic field work and writing (Maréchal, 2010 p. 43)." Auto-ethnography can be seen as:

"research and writing [are] socially-just acts; rather than a preoccupation with accuracy, the goal is to produce analytical, accessible texts that change us and the world we live in for the better ... aspire to purposeful and tension-filled "selfinvestigation" of an author's (and a reader's) role in a context, a situation, or a social world ...speaking in and through experiences that are unspeakable as well as inhabiting and animating the struggle for words and often our failure to find them" (Jones, 2005 pp. 763, 767, 772).

Tierney (1998, p. 66) believes -

"Autoethnography confronts dominant forms of representation and power in an attempt to reclaim, through self-reflective response, representational spaces that have marginalized those of us at the borders."

Ellis (2004, p xix) states that auto-ethnography is

"research, writing, story and method that connect the autobiographical and personal to the cultural, social and political".

John Maxwell "JM" Coetzee, 2003 recipient of the Novel Prize for Literature puts it that:

"In a larger sense, all writing is autobiography: everything that you write, including criticism and fiction, writes you as you write it (Coetzee, 1992, p. 17)."

In this research, the employment experiences of the first author (himself autistic) and his career trajectory spanning over 40 years were analyzed. This included the factors that influenced the researcher changing jobs 27 times in 27 years of his early to mid- career life. All job changes were initiated of his own accord. This also occurred in jobs that he liked and in which he excelled. The insights gained also explained the success of the strategies he used to stay in his last job for over 15 years before retirement. Arguably these workplace barriers, specifically affecting the first author - may also be relevant to other employees with autism. However, the aim of auto-ethnographic research is to create intrinsic and instrumental interest among the readers for the experience of a person with autism. 
For the readers to find points of resonance in their own experiences if they also happen to experience autism themselves and also for them to find resonance in the more than likely event that they know or work alongside someone who experiences autism. The employment insights resulted from analysis of extensive autobiographical materials that were then compared and contrasted with ethnographic interviews conducted with two neuro-typical participants who are age/cultural/ industry peers but who remained employed in a single organization for most of their careers. The first researcher's personal voice and the voices of other participants ("A" and "B") who were interviewed are written in indented parenthesized and italic text to indicate a verbatim quote. As a team effort, the first author's auto-biographical materials were often interlaced with the research team's voice switching in and out of first and third person writing styles in analyzing ethnographic materials. Individual aspects of the key findings will be systematically addressed and reported in the following sections.

Three key ASD-ness strengths-based employment insights emerged (Figure 1):

- Workplace Individuals Experience Insights;

- Workplace Institutional Expectations Insights; and

- Workplace Employee-Retention Insights.

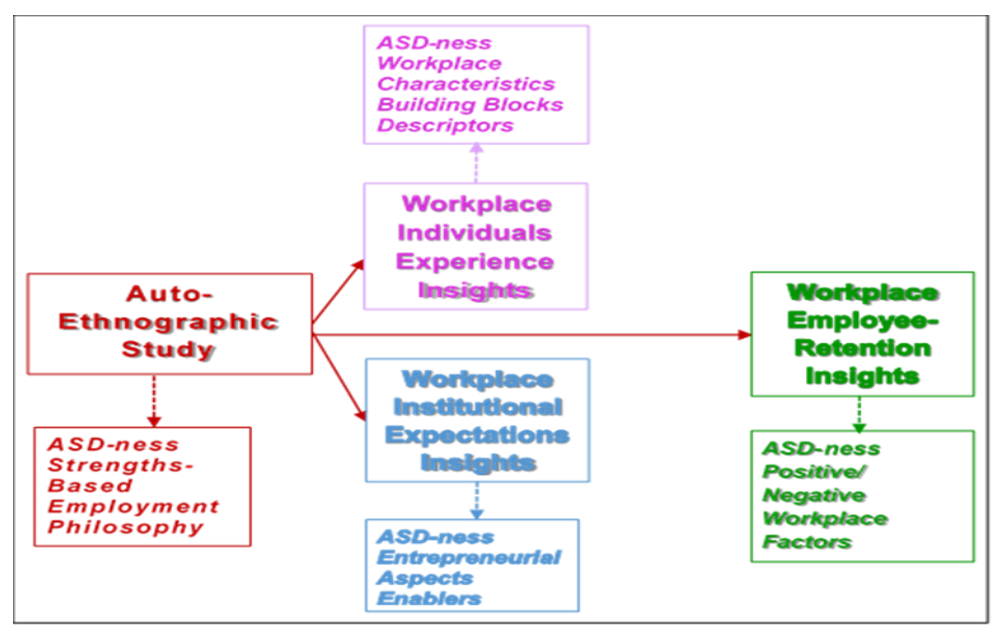

Figure 1. Auto-Ethnographic Investigation Framework

\section{Positive Autism: ASD-ness Strengths-Based Employment Auto- Ethnographic Insights}

"In retrospect, I was in a way lucky in that I did not realise I had autism till long after my retirement. Had I known that I had ASD then, I may have been constantly struggling to balance my autistic strengths with my autistic deficits in life and particularly in relation to establishing and retaining employment. I would not 
have been able to develop my occupational self-confidence (self-efficacy over different jobs, organizations, levels of employments ...) and my entrepreneurial spirit to achieve what I'm today - the Chancellor Emeritus of Ruijie University, China." (Wong, 2018 p 134, unpublished)

The first author is the person at the centre of the ethnographic research. Before his retirement in 2009, he was a sales and marketing consultant where his clients included Microsoft, Cisco and many other Fortune 500 companies. He also completed a doctorate in business, designed curriculum and authored publications on management and sales. Tables $1 \mathrm{a}$ and $1 \mathrm{~b}$ summarise the first author's education/career summary in Hong Kong, Australia and overseas.

"Although with the exception of two jobs, I had never been able to remain in a job for longer than 18 months, I demonstrated competence in my performance in every one of my jobs when I was working in Hong Kong and Australia. I had great success establishing employment but my challenge was keeping them." (Wong, 2018 p 90, unpublished).

To reiterate, the first author's employment-experiences were then compared and contrasted with the thematic analysis of interviews with two neuro-typical participants " $\mathrm{A}$ " and " $B$ " regarding their own long employment history and employment experiences. As each of them only worked for a single organisation throughout most of their careers until starting their own business, they had only one job interview experience. Personal interviews on the job would have been focused on career development as they progressed within their single organisation. Table 2 is an outline of their employment history.

Table 1a. First Researcher's Education/Career Summary in Hong Kong

\begin{tabular}{|c|c|}
\hline Age & Description/Employment/ Education (Hong Koeng) \\
\hline \begin{tabular}{l|l}
9. \\
19
\end{tabular} & $\begin{array}{l}\text { No school education till age nine due to delayed speech developenent and school changes nine } \\
\text { times due to "disorderty behaviours". }\end{array}$ \\
\hline 19 & $\begin{array}{l}\text { News Reporter, United Press Internaticenal (UPT), Hong Kong siv months: night shift- } \\
\text { transcribing recorded Chinese radio news to English; day shif- translating Chinese news in } \\
\text { Hong Kong popers to English and interviewing train passengers ffoen China to get first-bard } \\
\text { news. }\end{array}$ \\
\hline 19 & $\begin{array}{l}\text { Student at the Hoag Kong Polytech (formerly the Hong Kong Technical College, } \\
\text { HKTC). }\end{array}$ \\
\hline 20 & Probaticnary Police Inspector, Hong Kong. \\
\hline 22 & $\begin{array}{l}\text { Returned to the Hoag Kong Polytech (formerly the Hong Kong technical college, } \\
\text { HKTC). }\end{array}$ \\
\hline 23 & Dyebouse Technologist, Hong Kong/1s months. \\
\hline 24 & Trainee teacher at the HK Technical Teacher College. \\
\hline 25 & Quality Controt Manager at United States Testing/1S months, Hong Kong. \\
\hline 26 & Factory Quality Control Manager, Farah (General Pants) 12 months, Hong Kong. \\
\hline 27 & Factory Quality Control Manager at Britsport (Brittania Jeans)/12 months, Hong Kong. \\
\hline 28 & Quality Controt and Sourcing Manager, Genasco Hong Kong. \\
\hline 29 & Garment Factory Co-Owner of Wardorf Textiles/12 months, Hong Kong. \\
\hline 29 & Co-operative fishing partnership with a fishing county aear Guangzhou. \\
\hline 30 & $\begin{array}{l}\text { Unemployed } 10 \text { months, Hong Kong leading to approvals to migrate to Australia or to } \\
\text { work in the United States. }\end{array}$ \\
\hline
\end{tabular}


Table 1b. First Researcher's Education/Career Summary in Australia and Overseas

\begin{tabular}{|c|c|}
\hline Age & Description/Employment/Education (Australia and overseas) \\
\hline 30 & Factory Quality Control Manager, D Sportswear/12 months, Suburb of Sydney. \\
\hline 31 & Experimental Scientist, Division of Textile Physsies three years, Ryde, Sydney. \\
\hline 34 & Factory Manager, SM Dyeworks/12 months, Rural Town, Victoria. \\
\hline 35 & Sales Manager, B Chemicals/six months, Melbourne. \\
\hline 35 & Quality Control Manager, M Carpet/12 months, Suburb of Melbourne. \\
\hline 36 & $\begin{array}{l}\text { Laboratory Technician, Australian Wool Testing Authority (AWTA) three months, } \\
\text { Melbourne. }\end{array}$ \\
\hline 36 & Cobol Programmer, Maritime Services Board (MSB)/six months, Sydney. \\
\hline 37 & Programmer, Fairfield City Council/18 months, Fairfield, Sydney. \\
\hline 38 & $\begin{array}{l}\text { Systems Development Manager, Hawkesbury Shire Council/18 months, Hawkesbury, } \\
\text { Sydney. }\end{array}$ \\
\hline 40 & Personal Computers and Network Systems Manager, Genasys II/12 months, Sydeey. \\
\hline 41 & $\begin{array}{l}\text { Central Computer Support, Teacher, Technical and Further Education (TAFE), Mt. } \\
\text { Druitt, Ultimo, North Coast Institute of TAFE five years, NSW. }\end{array}$ \\
\hline 45 & $\begin{array}{l}\text { Computer Centre Manager, Hewlett-Packard (HP) six months, Kuala Lumpur, } \\
\text { Malaysia. }\end{array}$ \\
\hline 45 & Sales and Training Manager, SS/six months, Kuala Lumpur, Malaysia. \\
\hline 46 & Sales and Training Manager, TMS Consultancy/six months, Greater China Region. \\
\hline 46 & Managing Director, SL Consultancy/18 months, Greater China Region. \\
\hline 46 & $\begin{array}{l}\text { Established Rui Jie (formerly StartNet) High Touch Sales process which formed the } \\
\text { key sales and marketing programs of Rui Jie University. }\end{array}$ \\
\hline 47 & $\begin{array}{l}\text { Independent Consultant for the same three internal sales and management training and } \\
\text { consultancy companies, } 13 \text { years, Greater China Region. }\end{array}$ \\
\hline 60 - & $\begin{array}{l}\text { Chancellor Emeritus, Rui Jie University, China, writer and social researcher iseven } \\
\text { years, Gold Coast, Australia. }\end{array}$ \\
\hline
\end{tabular}

Table 2. Outline of Employment Situations of Participants "A" and "B"

\begin{tabular}{|c|c|}
\hline $\begin{array}{l}\text { Time- } \\
\text { Lines }\end{array}$ & Career History \\
\hline $\begin{array}{l}1959- \\
1999\end{array}$ & $\begin{array}{l}\text { Participant " } A \text { " joined "The Bark" in rural NSW Australia as a "Teller" and } \\
\text { wotked in various positicens through the bank network - middle managernent, senior } \\
\text { management, MD for a subsidiary of "The Bark" and retired as a "State" Manager. } \\
\text { Ore job for } 40 \text { years. }\end{array}$ \\
\hline 1999 to & $\begin{array}{l}\text { Participant "A" owns and ruas a successful Franchise business in the Far } \\
\text { North Coast of NSW since his retirement. }\end{array}$ \\
\hline $\begin{array}{l}1968- \\
1983\end{array}$ & $\begin{array}{l}\text { Participant "B" started as a factory trainee for "The Factory" in Hoag Koag } \\
\text { and worked in various positions through "The Factory" to the position of the } \\
\text { Chief Operating Officer for a subsidiary of "The Factory" in Singapore. "B" } \\
\text { worked there for } 15 \text { years till the closure of the subsidiary. }\end{array}$ \\
\hline 1983 - & $\begin{array}{l}\text { Participant "B" owns and runs a successful sweater manufacturing set-up in } \\
\text { Hong Kong and China till present. }\end{array}$ \\
\hline
\end{tabular}




\section{Building Blocks Descriptors}

A building block approach was adopted to analyse the ethnographic data. Building blocks provide a common language unpacking information.

"So if I have a process that can discover building blocks, the combinatorics start working for me instead of against me. I can describe a great many complicated things with relatively few building blocks." (Holland, 1992 p. 170)

Holland explained his building block concept with an illustration of the way police artists make a drawing of a suspect from witness's description before the days of computers.

"The idea was to divide the face into, say, 10 building blocks: hairline, forehead, eyes, nose, and so on down to the chin. Then the artist would have strips of paper with a variety of options for each: say, 10 different noses, 10 different hairlines, and so forth. That would make a total of 100 pieces of paper... the artist could talk to the witness, assemble the appropriate pieces, and produce a sketch of the suspect very quickly... by shuffling those 100 pieces of paper, the artist could make a total of 10 billion different faces, enough to sample the space of possibilities quite widely." (Holland, 1992 p. 170).

Based on Holland's building-block concept, four descriptors labelled from A to $\mathrm{D}$ were developed. Descriptor A is about ASD-ness employment strengths, Descriptor B is about workplace characteristics, Descriptor C is about interview assessment descriptors and Descriptor D is about entrepreneurial. For illustration purpose, Descriptor A is described in Table 3 below. Descriptors B, C, D and their applications in unpacking the biographic materials and interview transcripts will be discussed in the next article to come.

\subsection{Descriptor A: ASD-ness Employment-Strengths (AES)}

Descriptor A: The first set of building blocks (Table 3) describing ASDness employment strengths was developed from the ASD-ness characteristics identified by the Autism Spectrum Australia (2016) and Asperger/Autism Network (2017), as well as DSM-5 ASD Diagnostic Criterion B (2013). They are colourcoded to denote employment strengths (AES 1 to 4) followed by a letter of the alphabet. For example, "ES1a" refers to the sub-descriptor under "Fixation on Details or Intense Focus: Preference for spending time alone" and "ES3c,p" refers to sub-descriptors under " 'ASD-ness Personality-Behavioural Pattern: Relishing life's absurd, dark, or incongruous side', and 'Fair and Just: Tendency to relate to and defend animals'", 
Table 3. Descriptor A - ASD-ness Employment-Strengths Descriptors (ESD) ${ }^{1}$

\section{Employment Strengths Descriptors 1 (ESD1a-I): Fixation on Details or Intense} Focus-

Intense Focus:

Fixation on Details:

a. Preference for spending time alone; f. Systematic information processing;

b. Interest in arcane or off-beat fields of g. Attention to detail; knowledge;

h. Precise technical abilities;

c. Concentration for long periods of time i. Ability to notice small details of an idea, on reading, experimenting, writing etc;

d. Avoidance wasting time in some theory, number pattern, book, film, object or visual image; activities that appeal to neurotypical $j$. Ability to perform repetitive tasks where people; accuracy, rules and routine are important;

e. Some special interests to be channelled k. Commitment to quality; and into productive hobbies or even 1. Accuracy of work. careers, where the person may be creative or make new discoveries.

EmploymentStrengths Descriptors 2 (ESD2a-i): Cognitive/Visual Thinking-

a. Very high intelligence;

b. Good verbal skills; rich vocabulary;

c. Ability to absorb and retain large amounts of information, especially about topics of special interest;

d. Ability to think in visual images;

e. Self-motivated, independent learners;

f. Tendency to think outside the box and generate novel solutions to problems;

g. May show a strong aptitude for a particular field of study or topic;

h. Diversification in occupations; and

i. Education qualifications exceeding the requirements of the Australian and New Zealand Standard Classification of Occupations.

Employment Strengths Descriptors 3 (ESD3a-p): ASD-ness Personality-Behavioural Pattern-

Atypical/Unique Humour: Honesty:

a. Playing with language and create puns; e. Tendency to speak the truth-even if it's not

b. Enjoyment of sarcasm and satire; tactful or in one's self-interest;

c. Relishing life's absurd, dark, or f. Desire and tendency to follow rules. incongruous side; and

g. Strong work ethic;

d. Seeing through empty rhetoric or conventional pieties.

Desire to Learn to Connect:

Fair and Just:

h. Expended effort and energy to learn 1. Tendency to be unconventional, open-minded, social skills that do not come and tolerant; naturally;

$\mathrm{m}$. Intensely responsive when made aware of injustice;

i. Persevere in the face of rejection, $n$. Advocate for the underdog, victims of bullying confusion or frustration; or member of an oppressed group; 
j. Belief in the best of everyone o. Propensity to express caring in non-traditional (sometimes naively); ways; and

k. Acceptance of quirkiness or p. Tendency to relate to and defend animals. imperfection in others, and become a loyal friend.

Employment Strengths Descriptors 4 (ESD4a-d): Hyper- or hyporeactivity to sensory input or unusual interests in sensory aspects of the environment ${ }^{2}$ -

a. Apparent indifference to pain/temperature;

b. Adverse response to specific sounds or textures;

c. Excessive smelling or touching of objects;

d. Visual fascination with lights or movement.

\section{Conclusion}

To sum up, it is envisaged that the insights gained from this autoethnographic analysis will contribute to sustaining employment for people with ASD in competitive employment by adopting a positive autism philosophy of a strengths-based employment approach which, in a nutshell, regards ASD-ness as a source of employment strengths and autistic behavioural challenges as personal differences not deficits.

The next article will continue with discussions on

1. The emerging themes (Figure 2) upon unpacking the auto-ethnographic data based on the four descriptors developed from Holland's building block concept;

2. Developing strategies to understand and minimize points of dissonance caused by negative workplace barriers affecting employment participation for people with autism;

3. Enabling ASD-ness employment sustainability facilitators enhanced by positive workforce factors; and Encouraging knowledge-worker productivity practice in today's knowledge-based connected economy; and

4. Implementing Drucker-based ASD-ness entrepreneurial employment enhancement framework in order to inform an ASD-ness-strengths-based approach to success in employment of people with autism and their retention.

${ }^{1}$ Coloured background and/or letters codes are used for the purpose to distinguish different descriptors.

${ }^{2} S C 4 a-d$ can be viewed as strengths to some people with ASD when they are drawn/indifferent to these conditions. 


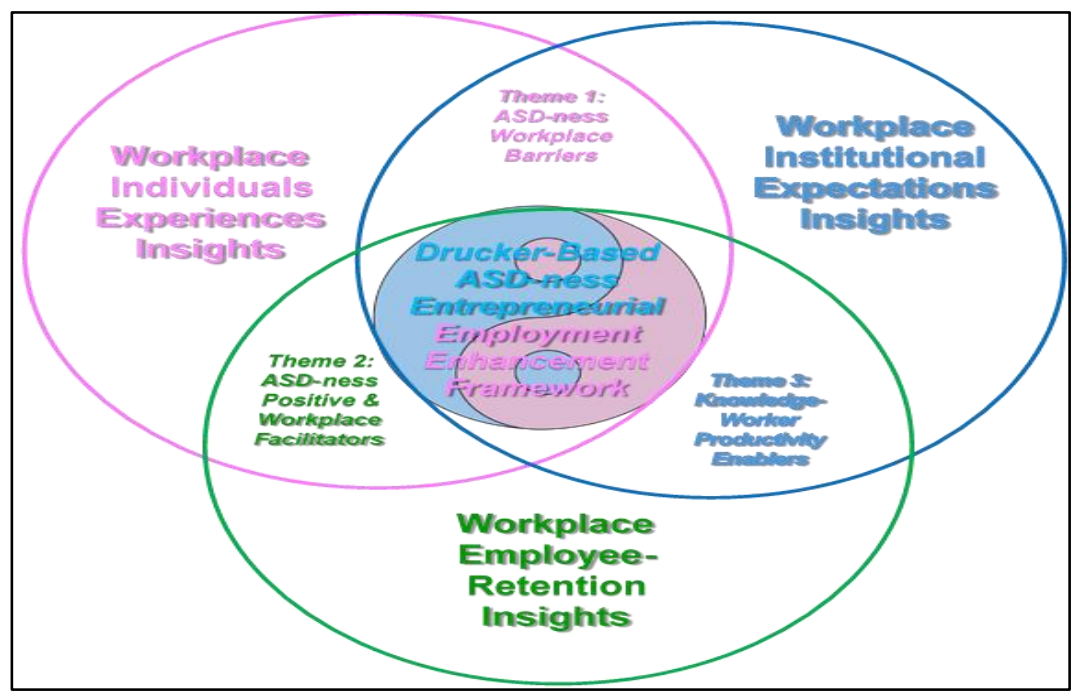

\section{References}

1. Artazcoz, L., et al., 2004. Combining job and family demands and being healthy: what are the differences between men and women. European Journal of Public Health, 14, 43-48.

2. Asperger H., 1944. Die Autistisehen psychopathen im kindesalter. Arch. Psych. Nervenkrankh. 117 76-136. 10.1007/BF01837709.

3. Asperger/Autism Network. 2017. [Online]. Asperger profiles: the big picture strengths. Available at http://www.aane.org/asperger-profile-strengths/. [Accessed 20 August 2017].

4. Autism Spectrum Australia. 2017. [Online]. Strengths and talents for employers. Available at https://www.autismspectrum.org.au/content/strengths-and-talentsemployers. [Accessed 20 august 2017].

5. Autism CRC. 2015. [Online] Program 3: Adulthood. Available at http://www.autismcrc.com.au/research-programs/adulthood. [Accessed 22 May 2015].

6. Autism Speaks. 2016. [Online] 10 years of progress: what we've learned about autism. Available at https://www.autismspeaks.org/news/news-item/10-years-progress-whatwe039ve-learned-about-autism. [Accessed 1 January 2017].

7. Ban, K.M., 2015. [Online] Remarks on World Autism Awareness Day. Available at https://www.un.org/sg/en/content/sg/speeches/2015-04-02/remarks-world-autismawareness-day. [Accessed 5 January 2018].

8. Barnhill, G.P., 2007. Outcomes in adults with asperger syndrome. Focus on Autism and Other Developmental Disabilities. 2007; 22(2):116-126. 
9. Billstedt, E. Gillberg, I.C. \& Gillberg, C., 2007. Autism in adults: symptom patterns and early childhood predictors. The use of the DISCO in a community sample followed from childhood. Journal of Child Psychology and Psychiatry, 48:11 (2007), pp. 1102-1110.

10. Clifton, D.O., \& Harter, J.K., 2003. Investing in strengths. In Cameron, A.K.S., Dutton, D.J.E., \& Quinn, C.R.E., eds. Positive organisational scholarship: foundations of a new discipline (pp. 111-121). San Francisco: Berrett-Koehler Publishers, Inc.

11. Coetzee JM (1992). Doubling the Point - essays and interviews. Edited by Attwell, D. Harvard University Press.

12. Drucker, P.F., 1999. Knowledge-worker productivity: the biggest challenge. California Management Review. Winter 1999, Volv. 41, No. 2.

13. DSM-5 2013. The Diagnostic and Statistical Manual of Mental Disorders, 5299.00 (F84.0).

14. Dudley, C. Nicholas, D.B. \& Zwicker, J.D., 2015. What do we know about improving employment outcomes for individuals with autism spectrum disorder? The School of Public Policy, SPP Research Papers, University of Calgary, Volume 8, Issue 32, September 2015.

15. The Economist. 2016. Beautiful minds, wasted. April 16, 2016, p. 9.

16. Ellis, C., 2004. The Ethnographic I: a methodological novel about autoethnography. Walnut Creek: AltaMira Press.

17. Falkmer, T., 2018. Longitudinal study of Australian autistic adults. Adulthood Program 3. Autism CRC. [Online]. Available at https://www.autismcrc.com.au/about-us/ourpeople/our-team/torbjorn-falkmer . [Accessed 18 February 2018].

18. The Guardian. 27 October 2016. 11 shocking statistics about autism and employment. [Online]. Available at https://www.theguardian.com/tmi/2016/oct/27/11-shockingstatistics-about-autism-and-employment. [Accessed 20 August 2017].

19. Harrop, C. \& Kasari, C., 2015. Learning when to treat repetitive behaviors in autism. Spectrum. [Online] https://spectrumnews.org/opinion/viewpoint/learning-when-to-treatrepetitive-behaviors-in-autism/. [Accessed 01 January 2018].

20. Harvard Mental Health Letter. 1999. What is solution-focussed therapy? Harvard Mental Health Letter, April 1997, Vol. 13 Issue 10, p8, Harvard Medical School.

21. Hendricks, D., 2010. Employment and adults with autism spectrum disorders: challenges and strategies for success. Journal of Vocational Rehabilitation 32 (2010) 125 - 134. DOI:10.3233/JVR-2010-0502 IOS Press.

22. Holland, J.H., 1992. In Waldrop, M., 1992. Complexity: the emerging science at the edge of order and chaos. Simon \& Schuster Paperbacks, New York.

23. Howlin, P., Alcock, J. \& Burkin, C., 2005. An 8 year follow-up of a specialist supported employment service for high-ability adults with autism or Asperger syndrome. SAGE Publications and The National Autistic Society Vol 9(5) 533-549; 057871 13623613(200512)9:5.

24. IACC, 2017. 2017 IACC Strategic plan for autism spectrum disorder research. Interagency Autism Coordinating Committee. [Online]. Available at https://iacc.hhs.gov/publications/strategic-plan/2017/strategic_plan_2017.pdf. [Accessed 06 January 2017]. 
25. Jones, H.S., 2005. Autoethnography: making the personal political. In Denzin, N.K. \& Lincoln, Y.S., eds. Handbook of qualitative research, pp.763-791. Thousand Oaks, CA: Sage.

26. Kanner, L., 1943. Autistic disturbances of affective contact. [Online]. Available at https://simonsfoundation.s3.amazonaws.com/share/071207-leo-kannerautistic-affective-contact.pdf. [Accessed 05 January 2018].

27. Kapp, S. K., Gillespie-Lynch, K., Sherman, L. E., \& Hutman, T., 2012. Deficit, difference, or both? Autism and neurodiversity. Developmental Psychology. [Online]. Available https://www.researchgate.net/profile/Kristen_Gillespie Lynch/ publication/224869514_Deficit_Difference_or_Both_Autism_and_Neurodiver sity/links/0912f504d11055a78c000000.pdf. [Accessed 20 August 2017].

28. Kim, T.J. \& von dem Knesebeck, O., 2015. Is an insecure job better for health than having no job at all? A systematic review of studies investigating the health-related risks of both job insecurity and unemployment. BMC Public Health 15:985 DOI 10.1186/s12889-015-2313-1.

29. Kivimäki, M., Vahtera, J., Hemingway, H. \& Pentti, J., 2001. Organisational downsizing and musculoskeletal problems in employees: A prospective study. Occupational and Environmental Medicine, 58, 811-817.

30. Kral, R., 1989. Strategies that work: techniques for solutions in the schools. Milwaukee, Wisconsin Institute on Family Studies.

31. Lorenz, T. \& Heinitz, K., 2014. Aspergers - different, not less: occupational strengths and job interests of individuals with Asperger's syndrome. PLoS ONE 9(6): e100358. doi:10.1371/journal.pone.0100358. June 2014 | Volume 9| Issue 6 | e100358. [Online]. Available http://journals.plos.org/plosone/article?id=10.1371/journal.pone. 0100358 [Accessed 20 August 2017].

32. Maréchal, G., 2010. Autoethnography. In Mills, A.J., Durepos, G. \& Wiebe, E., eds. Encyclopedia of case study research, Vol. 2, pp. 43-45. Thousand Oaks, CA: Sage Publications.

33. The National Autism Society. 2016. The Autism Employment Gap. [Online]. Available at file://C:/Users/peter/ Downloads/TMI\%20Employment\%20Report $\% 2024 \mathrm{pp} \% 20 \mathrm{WEB} \% 20(1)$.pdf. [Accessed 05 January 2018].

34. Orsmond, G.I et al., 2013. Social participation among young adults with an autism spectrum disorder. Journal of Autism and Developmental Disorders 43:2710-2719 DOI 10.1007/s10803-013-1833-8.

35. Pellicano, E., Dinsmore, A. \& Charman, T., 2014. What should autism research focus upon? Community views and priorities from the United Kingdom. Autism 2014, Vol. 18(7) 756-770 (C) The Author(s) 2014 Reprints and permissions: sagepub.co.uk/journals Permissions.nav DOI: 10.1177/1362361314529627 aut.sagepub.com.

36. Pickavance, N., 2014. The reconnected leader: an executive's guide to creating responsible, purposeful and valuable organisations. Kogan Page: London, Philadelphia, New Delhi. 
37. Ratto, A., Mesibov, G., 2015. Autism spectrum disorders in adolescence and adulthood: long-term outcomes and relevant issues for treatment and research. Science China. Life sciences September 2015 DOI: 10.1007/s11427-012-4295-x Source: PubMed.

38. Roux, A.M., et al., 2013. Postsecondary employment experiences among young adults with an autism spectrum disorder - RH: Employment in young adults with autism. Journal of the American Academy of Child Adolescent Psychiatry. 52(9): 931-939. doi:10.1016/j.jaac.2013.05.019.

39. Seltzer, M. M., et al., 2011. Adolescents and adults with autism spectrum disorders. In Amaral, D.G., G. Dawson, G. \& Geschwind, D.H., eds. Autism spectrum disorders pp. 241-252. New York: Oxford University Press.

40. Shattuck, P.T., et al., 2007. Change in autism symptoms and maladaptive behaviors in adolescents and adults with an autism spectrum disorder. Journal of Autism and Developmental Disorders, 37(9), pp. 1735-1747.

41. Tierney, W.G., 1998. Life history's history: Subjects foretold. Qualitative Inquiry, Vol 4, pp. 49-70. Sage Journal.

42. United Nations. 2014. The Convention on the rights of persons with disabilities training guide. Professional Training Series No. 19. [Online]. Available at http://www.ohchr.org/Documents/Publications/CRPD_TrainingGuide_PTS19 _EN\%20Accessible.pdf . [Accessed 01 January 2018].

43. United Nations. 2017. Equal opportunity for self-determination would empower persons with autism to make stronger positive impact. Secretary-General Says in World Observance Message. [Online]. Available at https://www.un.org/press/en/2017/ sgsm18476.doc.htm. [Accessed 24 August 2017].

44. Wong, P.S., 2018. How I succeeded despite autism: my childhood, education, family, work, and retirement (unpublished). 